\title{
ANALYZING THE DIVISION OF HOUSEHOLD LABOR WITHIN SPANISH FAMILIES
}

\section{ANÁLISIS DE LADIVISIÓN DEL TRABAJO DOMÉSTICO EN LOS HOGARES ESPAÑOLES}

\author{
Laia Balcells I Ventura \\ Centro de Estudios Avanzados en Ciencias Sociales. Fundación Juan March. Madrid \\ balcells@ceacs.march.es \\ Universidad de Yale. New Haven
}

\begin{abstract}
Do all women experience a labor "double burden"? Are women responsible for domestic tasks in all households? What explains variation in patterns of distribution of household labor across families? In this article, I approach these questions from the perspective of two opposing theoretical approaches: the New Home Economics framework, and the Social Capital or sociological framework. I test the validity of these two frameworks with data from the Spanish Fertility and Family Survey of 1995. The results point towards the validity of the sociological perspective: those families in which the husbands have medium labor status present more egalitarian patterns of household labor distribution. Additionally, the results confirm the importance of attitudinal variables such as religiosity to explain domestic labor division patterns: women with more traditional values experience a more severe double burden.
\end{abstract}

\section{Additional Keywords}

Cohabitation, Coupled Careers, Children, Gender Equality, Marriage.

\section{RESUMEN}

¿Experimentan las mujeres una doble carga laboral? ¿Son las mujeres responsables de las tareas domésticas en los hogares? ¿Qué explica la variación en patrones de distribución de trabajo doméstico que tiene lugar a través de las familias? En este artículo se abordan estas cuestiones partiendo de dos marcos teóricos opuestos: el marco de la New Home Economics, y el del Capital Social, que se ponen a prueba a partir de datos de la Encuesta de Fecundidad y Familia de 1995. Los resultados apuntan hacia la validez de la perspectiva sociológica: las familias donde el marido tiene un estatus laboral medio presentan patrones más equitativos de distribución del trabajo doméstico. Adicionalmente, los resultados confirman la importancia de variables actitudinales como la religiosidad para explicar patrones de división del trabajo doméstico: las mujeres más tradicionales son las que experimentan una mayor doble carga.

\section{Palabras Clave Adicionales}

Carreras conjuntas, Convivencia, Hijos, Igualdad de género, Matrimonio. 


\section{INTRODUCTION 1}

The most remarkable characteristic of the current division of household labor is that, whether employed or not, women continue to do the majority of housework (Shelton \& John 1996). This "double-burden" for working women has special relevance in countries like Spain, where "the new role of women has had to coexist with the lagging development of institutions, which cannot guarantee that forming a family or having children will not create conflicting interests with their individual career paths." (González-López 2001:146-147) It is however difficult to believe that the unequal division of household labor exists in a homogeneous way across society-that is, that this double burden takes place in the same way across all families. In this paper, I undertake a set of analyses on patterns of division of household labor among Spanish families in order to check if, as I suspect, there is a variation in these patterns, on the one hand, and to explain this variation, on the other. I am interested in studying these patterns at both an individual and a family level perspective; in particular, I will examine how the different characteristics of family members -mainly of husband and wife- affect the way in which household labor is distributed between them².

With this aim in mind, in this paper I take into account previous explanatory models on careers of couples, which have focused on explaining labor market participation and attainment of women by considering husband's labor market resources as a key explanatory variable (see, for example, Bernardi 1999, Blossfeld and Drobnic 2001). My aim is not only to explain labor market participation and attainment of women, as these authors do, but also women's degree of engagement in household labor. Indeed, the purpose is to analyze if models that have proved useful in explaining an apparent "dichotomous" decision of women (i.e. whether to become homemakers or not) can also explain a "continuous" decision of women (i.e. the degree to which they are responsible for housework). In general, the idea is to provide new insights in the study of the division of household labor, and to improve the understanding of its variation across society.

The paper is organized as follows: in the next section, I present the theoretical framework of the paper and I introduce the set of alternative hypotheses to be tested. In section 2, I present the data and variables with which I will perform the empirical test. In section 3, I present and discuss the results of the empirical test. Section 4 concludes the article.

\footnotetext{
${ }^{1}$ I thank Héctor Cebolla Boado and Gôsta Esping-Andersen for their comments on a previous version of this article.

${ }^{2}$ In this paper I focus on heterosexual families.
} 


\section{THEORETICAL FrameWork}

Since the final decades of the twentieth century, the progressive incorporation of women into the labor market has entailed a great number of changes in various aspects of familial life in industrialized societies. The traditional division of labor within the household, consisting of the specialization of the man/husband in the labor market (henceforth, also LM) and the specialization of the woman in housework, has been particularly influenced by the incorporation of women into the $\mathrm{LM}^{3}$ It is quite clear that many women are currently dedicating a large part of their day to paid work and, if they are also interested in following a career, they will not be able to do as much of the household duties as they did before. However, it is still not clear how these responsibilities, traditionally held by the woman, are then distributed between members of the family.

Most academic research in the area has suggested that there is a significant and unequal pattern of acquisition of responsibilities: while women are continuously increasing the proportion of their time dedicated to work (the sum of housework and paid work) - as opposed to time dedicated to leisure, men are not. In other words, men are not being incorporated into the world of housework to the same extent that women are being incorporated into the LM: "In general, female paid employment has increased but at the expense of maintaining the double burden of work inside and outside the housework" (González-López 2001: 151). This double burden has clear consequences on working women's careers both because they are more likely to interrupt their careers due to family issues (e.g. illness of children, the elderly, etc.), and because they cannot make the same level of investment in human capital as men. Indeed, housework implies a lower degree of investment in human capital (and therefore less returns) because it is a limiting force over energy and effort ${ }^{4}$.

There are various factors that may affect the distribution of labor within families (and the nature of women's LM careers in the case of dual-earner partnerships), the type of welfare state regime being one of the most relevant. Esping-Andersen (1990) distinguishes between three types of welfare state regime depending on their modality of "decommodification" of the labor market (his typology distinguishes between corporatistconservative, liberal and social-democratic welfare regimes). ${ }^{5}$ Welfare state institutions have an important impact on female's labor market career, as they may permit a more

\footnotetext{
${ }^{3}$ In this paper, I use a conventional definition of housework, which I conceive as household labor: "unpaid work that is done to maintain family members and/or a home" (Shelton \& John 1996:300). I do not deal with "emotion" work or what Shelton \& John call "invisible" work.

${ }^{4}$ Hersch (1991a, quoted in Hersch and Stratton 1994) finds a negative effect on wages of time spent on housework for women, controlling for human capital characteristics, number of children, and marital status.

5 The two main contemporary (non-historical) indicators of "welfare state regime" are "degree of decommodification" (the degree to which a social service is a matter of right, and degree to which a person can maintain a livelihood without reliance on the market) and "stratification" of the welfare state.
} 
or less continuous career of women who create a family or who have children. Indeed, if these institutions are such that they allow families to allocate a share of their domestic responsibilities with external (non-market) agents such as the state, women have more opportunities to follow a continuous professional career. Furthermore, some institutions of the welfare state such as "parental leave" for males facilitate the acquisition of some domestic (traditionally female) activities by men -and therefore, they facilitate a more equal distribution of housework within the household.

However, what if the welfare state does not allow a familial release from these domestic tasks, or they do not promote a more equal distribution of them between the couple? In these cases, how do families deal with women's incorporation into the LM? As stated by Gónzalez-López, this is clearly the case for Spain, a country where "working parents can barely count on state support to combine family responsibilities and paid work. The lack of assistance reinforces the traditional one-earner family model or encourages women to interrupt their careers (2000: 29). While dual-earners families are increasing in numbers, we know little on what are the patterns of distribution of housework labor within these families, and what are the variables explaining the fact that some families present a certain type of distribution of housework (e.g. women responsible of all housework), while others present another type of distribution (e.g. women sharing housework responsibilities with the husband). In other words, the determinants of division of domestic labor are still a "black box" that requires further scrutiny.

From my point of view, the distribution of housework labor within families requires both an individual-level and a family-level explanation. Individual factors such as the labor status of women are likely to matter. But also, factors relative to the couple are likely to have an important explanatory power. For example, Hersch and Stratton (1994) note that husbands do less housework than their wives as their relative earnings and hours spent in the labor market increase. As I said, a number of recent studies have analyzed the evolution of women's careers in relation to their husbands' job market position or employment status (Bernasco et al 1998, Blossfeld and Drobnic 2001, Bernardi 1999a 1999b, González-López 2001). These studies have analyzed the influence exerted by the person with whom the subject is likely to spend the greatest part of her life -namely her partner- into her participation in the LM and into its outcomes (Bernardi 1999: 285). Based on the New Home Economics (NHE) framework (Becker 1981), most of these authors have hypothesized that the husband's LM resources have a negative effect on the wife's participation in the LM, as well as on the outcomes of her participation (that is, her occupational attainment). That is because the higher occupational status of the husband implies a higher comparative disadvantage for the woman in the LM, and this entails a lesser propensity of the woman to participate in it, as well as a lesser effort in paid work when she does participate. This rationale comes from the assumption that, within the household, men and women pool their resources and try to maximize their joint benefit (Becker 1981), and it implies that the specialization of women in the household is an efficient decision in terms of the maximization of household welfare. 
Authors like Bernasco et al. (1998) and Bernardi (1999) suggest that there is an alternative hypothesis on the effect of the husband's employment on women's LM participation and attainment, which goes in the contrary direction of the NHE hypothesis. This second hypothesis is based on the concept of Social Capital -in Coleman's (1988) definition of this term. ${ }^{6}$ Namely, it refers to the positive effect that the husband's position in the labor market can have on the wife's LM participation and attainment: this can occur because the resources of the husband are shared and exchanged with those of the wife; thus, the woman obtains a benefit, in terms of human capital, from having a husband with labor market resources. "Being married to a husband who has a high position in the LM might have positive results for the wife's employment, in terms of disposable information, direct transmission of human and cultural capital, and personal influence in the job-matching process" (Bernardi 1999b: 285). Even if none of these studies have totally rejected the NHE hypothesis in favor of the social capital hypothesis, the latter seems to be quite a powerful one: Bernardi (1999a; 1999b) analyzed the work histories of married women in Italy and observed that while the NHE hypothesis explain wives' LM participation (i.e. husbands' resources have a negative effect on this), the sociological hypothesis explain wives' occupational attainment (i.e. husbands' resources have a positive effect on this).

I would argue that each of these studies provides interesting insights into the understanding of the division of household labor. For instance, they help us to generate questions such as: what can we expect to be the effect of husband's employment status on the allocation of time (between LM work and housework) of wives who decide not to become homemakers? ${ }^{7}$ In the case of employed women, is the husband's occupational status an important variable for explaining the division of household labor? In fact, by adopting this approach, we can derive a set of alternative hypotheses:

According to the NHE framework, we would expect that the employment status of the husband would have a negative effect on his level of contribution to the housework. That is the case because the greater the labor market resources of the husband, the greater his comparative advantage in the labor market - so it is more efficient (in terms of the couple) for him to dedicate more hours in market work while she dedicates less hours in market work and more hours in housework. In addition, we might expect that the level of housework responsibilities of the husband would be lower if he has greater employment status because he has greater bargaining force within the couple: indeed, when the husband has more economic resources, he has a higher "threat point", consisting in that

\footnotetext{
${ }^{6}$ The social capital hypothesis is included within a more general framework, the so-called "sociological" framework, which also makes reference to the type of Welfare State institutions, and to the different gender identities prevailing in a certain society (Bernardi 1999a).

${ }^{7}$ These studies have mainly focused on the study of transitions in or out the labor market of married women. They have not taken into account the determinants of distributions of household labor that do not imply a complete specialization of women in housework.
} 
he can say that he is going to buy the services in the market instead of doing the tasks himself. ${ }^{8}$ As noted by Gronau (1976) (even though he is referring to wage levels rather to employment status), if both partners are working, an increase in the husband's wage will lead the wife to allocate more time to household production and less time to market work; however, an increase in the wife's wage makes the husband take more leisure and do less market work. Yet, in a society where there are market substitutions for domestic work, the relationship may not be the same; in this case an increase in the male's wage may induce employed women to decrease their number of hours of paid work and to increase their leisure time -that is, an increase in the husband's wage may have no effect on the distribution of household labor, which will remain equal. ${ }^{9}$

According to the sociological framework, the woman's degree of involvement in domestic work should not increase with a rise in her husband's occupational status. And, even if we cannot provide with a direct mechanism by which the effect should be like this, we can think of an indirect mechanism: if the husband transfers part of his resources to the woman and she consequently achieves a higher level of human capital, she will be more interested in investing in the labor market rather than in the household. That is because the returns are comparatively higher than those she would obtain without these social capitalgiven resources. Since both members of the couple will be interested in not lowering their degree of investment in the LM, they will probably seek external-tothe-couple aid for domestic tasks. The likelihood of depending on external people for domestic tasks is therefore likely to increase with a raise in the occupational status of the husband. However, the use of these substitutive resources from outside the couple is obviously conditional on their availability -that is, the existence of people within the family able to take over these responsibilities, or the existence of a level of market supply of these resources.

In brief, according to the NHE framework we can expect to observe a positive relationship between a husband's labor market status and his wife's degree of domestic responsibilities. According to the social capital framework, we can expect a negative relationship between a husband's labor market status and his wife's degree of domestic responsibilities -which will probably not be related to a higher degree of involvement of the husband in domestic tasks, but to a delegation of these responsibilities to external-tothe-couple people.

In this paper I will explore these two hypotheses, as I consider that this should provide us with more information about the determinants of patterns of distribution of household

\footnotetext{
8 This argument comes from Becker's H-C theory (1981) and bargaining models within the couple, which Shelton and John explain have their origins in the work of Blood and Wolfe (1960)-according to these models, the individual with most resources (education, earnings, occupational prestige) always uses those resources to negotiate his/her way out of housework (Shelton and John 1996: 304).

${ }^{9}$ In any event, we cannot a priori think that these market substitutions will exist in Spain, where there is not an extended market of welfare services (they only exist at a high price because the offer is small).
} 
labor within families. In the next section, I present the results of an empirical test I have performed using data on Spanish women and their families. Even though I will be testing the hypotheses presented above by including "husband's occupational status" as an independent variable in the model, I will also consider additional variables in my analysis. Specifically, I will consider the following independent and control variables:

1. Structural and situational variables, which refer to the demographic characteristics and socioeconomic resources owned by the individuals on a long-term basis (such as age or education), or on a medium-term basis (such as having children living at home) (Morales 2000).

2. Dispositional variables, which refer to the attitudes or preferences held by women in relation to their role as homemakers and/or paid workers. In this regard, I will consider Hakim's work (1996) as a benchmark for the analysis of preferences. I will try to observe whether a pattern of different "types of women" emerges in Spain, and if the values or set of expressed preferences over "career" and "family" of the women have an effect on their level of LM participation and on their share of housework responsibilities.

\section{Data and Variables}

In my empirical test I focus on married/cohabiting couples in Spain, ${ }^{10}$ and -as I have pointed out above- I focus on observing the effect of a set of variables (husband's occupational status among) on wife's LM participation and attainment -on the one hand- and on her degree of housework responsibilities-on the other. ${ }^{11}$ In both cases, I am interested in contrasting the "sociological" framework to that of the NHE.

\section{Data}

The database used is the Centro de Investigaciones Sociologicas (CIS) Study 2182, entitled: "The Spanish survey on fecundity and family" (FFS/ONU) (Encuesta de fecundidad $y$ familia). The data was collected between June $6^{\text {th }}$ and November $2^{\text {nd }} 1995$, from a representative sample of Spanish women from 18 to 49 years old; the database has a total of 4,021 cases. However, since I am interested in analyzing the patterns of LM participation and of housework responsibilities of either married or cohabiting heterosexual women, the size of the sample that I will be using is in fact smaller (the total number of married/cohabiting women in the sample is 2,508 ).

\footnotetext{
${ }^{10}$ I combine married and cohabiting couples under a single category. And, in the same way, when I refer to 'married women', I am referring to both married and cohabiting women.

${ }^{11} \mathrm{I}$ am interested in analyzing the effect of employment status -rather than wage, education or other kind of resources- because this resource is the least studied in terms of its potential effects on the division of household labor (Shelton and John 1996: 305-6).
} 


\section{Dependent Variables}

I will work with four different dependent variables. All of them are limited dependent variables, but while three of them have a binomial nature, one has a multinomial nature. I will be using different estimation methods (binomial logit and multinomial logit) accordingly.

1- Active: it has value 1 if the woman is active and value 0 otherwise..$^{12}$ It will allow us to observe the effect of the independent variables on the likelihood of being in the LM. I will estimate the model for this dependent variable with a binomial logit.

2- Active_and_working: it has value 1 if the woman is active and employed and value 0 otherwise. ${ }^{13}$ It will allow us to see the effect of the independent variables on the likelihood of being employed. The estimation model for this dependent variable will also be a binomial logit. ${ }^{14}$

3- Housework: this is a variable that I modify in three different ways in order to perform different analyses on the distribution of domestic tasks between members of the couple and/or of the family. ${ }^{15}$ All of them are created from a set of questions on who bears responsibility for different household tasks. ${ }^{16}$ From four of these questions -those that refer to the main domestic tasks (cooking, shopping, vacuuming, and washing up) - I have classified women into five different categories: ${ }^{17}$

- Women who are totally responsible for domestic tasks. A woman is included in this category if she declares that she is responsible for at least 3 tasks.

- Women who share domestic tasks with their couples. If a woman declares that she is responsible for 2 of the tasks and her couple is responsible for 2 of them; or if the couple

12 Thus, a woman who is active but not working has value 1 in this variable.

${ }^{13}$ Thus, a woman who is active but not working has value 0 in this variable.

${ }^{14}$ Also, the variable active_and_working will be used as a control variable in the models for housework responsibilities (that is, the models with the dependent variables housework2 and housework4).

${ }^{15}$ I use this operationalization of housework (instead of looking at the total amount of time dedicated to housework) because of the nature of the data available. Also, because I am interested in observing how tasks are distributed between distinct members/non-members of the family.

${ }^{16}$ For each task, each individual is asked to say who is responsible for it: herself, her partner, both of them, other people in the household, or other people (not in the household).

17 Thus, the indicator does not include minor domestic tasks such as "managing the household budget" because, even if some of them may have an important symbolic meaning (i.e. in terms of who has control of the household expenses), they do not require as much time investment, and they do not require a daily commitment. 
is sharing responsibility for 3 or 4 tasks.

- Women who share domestic tasks with others members of the family or with external people. If she does 2 of the tasks and other members (who are not part of the couple) do 2 of the tasks.

- Women who are not responsible for a large part or not responsible at all for domestic tasks. If a woman does one task or she does no tasks.

- Others. This category includes the remaining cases, not included in the categories above.

From these categories, I have created two different dependent variables that are theoretically relevant:

3.1- Housework2 is a two category dependent variable that measures the extent to which housework tasks are shared with the husband. It takes value 1 if women are in category 2 above, and it takes value 0 if women are in category 1 . I do not take in account other categories of women because I want to contrast "totally responsible" women with "sharing with husband" women. ${ }^{18}$

3.2- Housework4, is a four category dependent variable which has value 1 for the category 1 above, value 2 for category 2 , value 3 for category 3 , and value 4 for category 4. I will estimate the likelihood of being in each of these categories. ${ }^{19}$

\section{Independent Variables}

I divide the independent variables into two groups: a set of variables related to demographic and socioeconomic characteristics of the individual (structural and situational variables), and a set of variables related to values or attitudes of the individual (dispositional variables).$^{20}$ I will be introducing these variables in two different steps:

\footnotetext{
${ }^{18}$ I have not been able to create a category such as "man totally responsible" for domestic tasks because there are almost no cases in which the husband does 3 or 4 of the tasks, so I have to limit my analysis to the distinction "sharing" vis-à-vis "not sharing" responsibilities with the couple.

${ }^{19}$ I do not take into account category 5 because I cannot give a substantive meaning to this category. It would not make sense to analyze the effect of some independent variables on this category or to oppose the probability of this category vis-à-vis the others.

${ }^{20}$ Hersch (1991) analyzes the time spent in housework activities as a function of the market wage rate and individual variables. He categorizes the latter into three types: individual household characteristics, cultural differences and attitudes. I prefer to distinguish between those variables related to the socio-demographic characteristics of the individual/household -that its, structural and dispositional ones- and those related to her
} 


\section{Structural and situational variables}

Age: years of the interviewed woman. We can expect that younger women are more likely to participate in the LM, and that they are more likely to share housework responsibilities.

Children: I create three categories in order to better capture the differences that exist between families with children of different ages. I build three variables: Child_less3: number of children under 3 years old; Child_less14: number of children between 4 and 14 years old; Child_less30: number of children between 15 and 30 years old living at home. ${ }^{21}$ We expect that having children has a negative effect on women's LM participation and attainment, and that the younger the children, the greater the effect. We also expect that having children who are under three decreases the probability of sharing domestic responsibilities for women because of the lack of parental policies in Spain (e.g. there was not any type of parental leave for men in this country in 1995).

Education: I consider both the level of education of the woman and the husband. This variable is coded from data on the highest level of studies that the individual has done. I call these two variables education (for the wife) and husb_education (for the husband) and they have value 1 for elementary education or less, value 2 for secondary education or equivalent, and value 3 for tertiary studies (both college and graduate school levels).

Employment status: I take into consideration the employment status of the husband in order to test what is the effect of the employment status of the partner on the woman's LM participation, her LM attainment (i.e. if she works or she is unemployed), and her allocation of time between housework and paid work. In order to measure employment status, I use the ISEI scale created by Ganzeboom and Treiman (2003). ${ }^{22}$ The range of the scale is 16-90: the higher the value on the scale, the higher the employment status of the individual. I use the information in the survey on the occupation of the husband in order to locate him on the different categories of the ISEI scale. For this operation, I rely on the conversion tools in Ganzeboom and Treiman (1993). ${ }^{23}$ Once I have a value in the ISEI prestige scale, I create three categories of individuals (this will allow to test for non-linear effects): from 16-35, category 1 (Husb_Status1); from 36-55, category

\footnotetext{
attitudes -that is, dispositional ones-.

${ }^{21}$ Note that a woman without children will have value 0 in all these variables.

22 "We conceive of ISEI as measuring the attributes of occupations that convert a person's education into income. Accordingly, ISEI scores were generated by an optimal scaling procedure in which scores were assigned to occupation unit groups in such a way as to maximize the indirect effect of education on income through occupation and to minimize the direct effect of education on income, net of occupation (with both effects net of age)" (171).

${ }^{23}$ This allows me to convert the ISOC scale in the survey into the ISEI scale.
} 
2 (Husb_Status2); from 56 to 75 , category 3 (Husb_Status3). I will introduce these variables as dummies in the models, leaving Husb_Status1 as the base category. ${ }^{24}$

\section{Dispositional variables}

Religiosity: we can expect that "women and men with more traditional sex attitudes will have a less equal division of household labor than those with less traditional attitudes. Specifically, men with more traditional sex role attitudes are expected to spend less time on housework than those with less traditional attitudes, while the reverse is expected for women" (Shelton and John 1996:306). There are no questions relating to sex role attitudes in the CIS survey, but degree of religiosity of the individual can be used as a proxy of traditional attitudes. I take into account both religiosity of the woman and religiosity of the husband. I expect that more religious people (both women and men) will be more supportive of the traditional division of roles within the household. ${ }^{25}$ The indicator of religiosity I use is a self-evaluation of religiosity (for wives), and evaluation of the couple's religiosity (for husbands). I create two dummy variables: Religion, which has value 1 if the woman considers herself religious or somewhat religious and 0 if she considers herself not religious; Husb_religion, which has value 1 if the woman considers her couple/husband religious or somewhat religious, and 0 if she considers her husband not religious. ${ }^{26}$

Preferences on work and family: following Hakim (1996) and Esping-Andersen (2002) I take into consideration preferences on division of domestic responsibilities held by the women. The survey has four questions that make direct reference to very distinct type preferences over family and work, and from which I construct four dummy variables: 1 if women hold the values either to some extent or totally (they to some extent or totally agree with the statement made in the question), and value 0 if they to some extent or totally do not hold them (they to some extent or totally disagree with the statement). The statements are the following:

\footnotetext{
${ }^{24}$ I was considering introducing another variable related to husband employment: work hours. As noted by Shelton and John (1996), "few studies consider the relationship between men's work hours and their wives' housework time" (307). Husband's number of work hours should have a positive effect on the wife's housework responsibilities. However, the inclusion of this variable implied a potential problem of endogeneity (namely, the level of housework responsibilities of the wife is likely to have a positive effect on the number of work hours of the husband). I have therefore decided not to include it.

${ }^{25}$ Besides the connection of religiosity with traditional sex attitudes, it must be noticed that Catholicism, which is the religion of the majority of the Spanish population, is especially sympathetic of traditional family roles.

${ }^{26}$ The individual is asked: "Do you consider yourself a religious person?", and "Is your couple/husband a religious person?"
} 
a) Couple_top: "Having a good relationship is the most important thing in my life".

b) Couple_most: "I dedicate a lot of effort in order to achieve a good relationship, even if this implies limiting my opportunities to achieve other personal objectives".

c) Profession_most: "It is very important for me to have a profession in which I can make some achievements".

d) Profession_top: "I make as much effort as necessary in order to advance in my profession".

Variables a and b are capturing what Esping-Andersen calls "family-centered women", while variables $c$ and $d$ are capturing the set of preferences of "career-centered women".

\section{RESULTS}

In Table 1 we can observe the results of the explanatory model for the first dependent variable: active. Model 1 includes structural and situational independent variables; model 2 adds dispositional variables to the first model.

The results are pretty coherent with the literature, and with what we expected: having children has a negative effect on the woman's presence in the LM, and the effect decreases with the age of the kids (women with children under three are those less likely to be active in the labor market). Also, education has a positive effect on a woman's LM participation and the effect is non-linear: it increases with the level of education. Contrary to what was expected, neither the husband's education nor his employment status have an effect on the wife's participation in the LM. This result does not allow us to reject either the NHE hypothesis or the sociological one. The introduction of the dispositional variables (in model 2) produces little changes on the estimated effect of variables in model 1. We observe that attitudinal variables are significant: religiosity decreases the odds of being in the job market, and attitudes towards work/partnership are important too. The only problematic issue with these findings is that they could be hiding an endogeneous relationship (non-working women developing family oriented attitudes, and vice-versa for working women). ${ }^{27}$

In Table 2 we can observe the results of the explanatory model for the dependent variable active_and_working. Results do not differ much from those obtained for the dependent variable active (see above). However, the labor status of the husband appears as significant in this model and it has a positive coefficient: having a husband with a medium employment status (vis-à-vis having a husband with a low employment status)

\footnotetext{
${ }^{27}$ Since it is impossible to control for this endogeneity issue with the nature of the data available, we will have to take these results with some caution.
} 
Table 1.

Explanatory model for LM participation of women.

\begin{tabular}{|c|c|c|c|c|}
\hline & \multicolumn{2}{|c|}{ Model 1} & \multicolumn{2}{|c|}{ Model 2} \\
\hline & \multicolumn{2}{|c|}{ (S tructural and S ituational V.) } & \multicolumn{2}{|c|}{ (Dis pos itional V.) } \\
\hline & Coefficient & Rob. St. Error & Coefficient & Rob. St. Error \\
\hline Cons. & $-0,0005$ & 0,41 & $-0,30$ & 0,47 \\
\hline Age & 0,0002 & 0,01 & 0,003 & 0,01 \\
\hline Child_less3 & $-0,64^{\star * *}$ & 0,1 & $-0,52^{\star \star *}$ & 0,11 \\
\hline Child_less 14 & $-0,4^{\star \star *}$ & 0,06 & $-0,31^{* * *}$ & 0,066 \\
\hline Child_less 30 & $-0,37^{\star * *}$ & 0,08 & $-0,26^{* * *}$ & 0,085 \\
\hline \multicolumn{5}{|l|}{ Education } \\
\hline Secondary & $0,45^{* * *}$ & 0,11 & $0,4^{* * *}$ & 0,13 \\
\hline Tertiary & $1,87^{* \star *}$ & 0,2 & $1,67^{* * *}$ & 0,23 \\
\hline \multicolumn{5}{|l|}{ Hubs_education } \\
\hline Secondary & 0,07 & 0,27 & 0,17 & 0,27 \\
\hline Tertiary & 0,35 & 0,31 & 0,33 & 0,32 \\
\hline \multicolumn{5}{|l|}{ Husb_status } \\
\hline Husb_status2 & 0,06 & 0,09 & 0,06 & 0,11 \\
\hline Husb_status 3 & -0.029 & 0,18 & $-0 ., 45$ & 0,19 \\
\hline Religion & & & $-0,21^{* *}$ & 0,09 \\
\hline Husbreligion & & & $-0,07$ & 0,08 \\
\hline Couple_top & & & $-0,114$ & 0,12 \\
\hline Couple_most & & & $-0,37^{* * *}$ & 0,14 \\
\hline Profession_most & & & $1,02^{\star * *}$ & 0,12 \\
\hline \multirow[t]{3}{*}{ Profession_top } & & & $0,28^{* *}$ & 0,12 \\
\hline & \multicolumn{2}{|c|}{$\begin{array}{l}\text { Observations: } 2252 \\
\text { Wald Chi2 } 2(10)=214.93 \\
\text { Prob }>\text { Chi } 2=0.0000 \\
\text { Pseudo R2 } 2=0.0896\end{array}$} & \multicolumn{2}{|c|}{$\begin{array}{l}\text { Observations: } 1905 \\
\text { Wald Chi2 }(10)=276.26 \\
\text { Prob }>\text { Chi2 }=0.0000 \\
\text { Pseudo R2 }=0.1378\end{array}$} \\
\hline & \multicolumn{2}{|c|}{ Significance: ${ }^{*} .1^{* \star} .05^{* * \star} .01$} & & \\
\hline
\end{tabular}

increases the odds of being an active and employed woman. This goes somewhat in the opposite direction to what is observed by Bernardi (1999) for Italy and González-López (2001) for Spain. ${ }^{28}$ Thus, the sociological hypothesis (and not the NHE) is to some extent supported by these results: the woman is benefiting from the higher employment status of the husband, and this probably is the case because there is some sort of spillover

${ }^{28}$ Even though my specification of the dependent variable and my statistical model are different from theirs. These authors are undertaking event-history analysis, while I am doing a cross-sectional analysis. Also, my specification of attainment focuses only on being employed or not, while they focus on the level of occupational status attained. 
effect in terms of social capital resources. Yet, this does not happen with all categories of employment status of the husband: at the highest category it is not statistically significant. We can observe that the variables education, children, religiosity and family attitudes have approximately the same type of effect as in the previous model.

Table 2.

Explanatory model for LM participation and employment of women

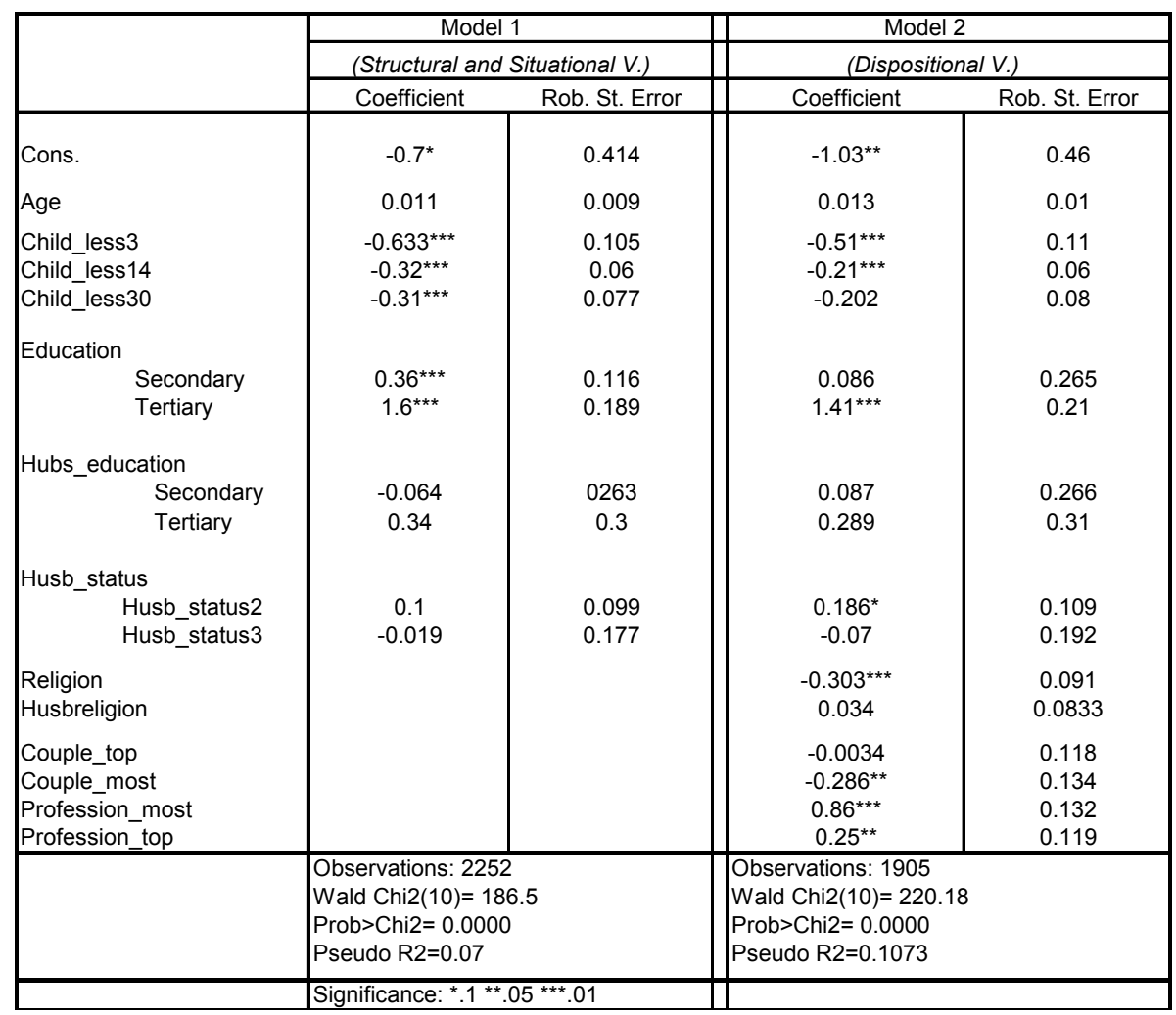

In Table 3 we can observe the results of the models estimated with the dependent variable housework2: they estimate a woman's probability of sharing domestic work with her partner. The results of model 1 and 2 show that a number of structural and situational variables have a statistically significant effect on the odds of "sharing with the husband", and that a number of dispositional variables are significant, as well. Again, the introduction of the latter set of variables does not much change the effect of the former set of variables. 
Table 3.

Explanatory model for division of domestic labor (Housework2)

\begin{tabular}{|c|c|c|c|c|}
\hline & \multicolumn{2}{|c|}{ Model 1} & \multicolumn{2}{|c|}{ Model 2} \\
\hline & \multicolumn{2}{|c|}{ (Structural and Situational V.) } & \multicolumn{2}{|c|}{ (Dispositional V.) } \\
\hline & Coefficient & Rob. St. Error & Coefficient & Rob. St. Error \\
\hline Cons. & $-3.10^{* *}$ & 1.5 & -2.57 & 1.68 \\
\hline Age & $-0.04^{* *}$ & 0.022 & $-0.036^{* *}$ & 0.026 \\
\hline Child_less3 & -0.3 & 0.23 & -0.199 & 0.257 \\
\hline Child_less14 & $-0.373^{* * *}$ & 0.135 & -0.203 & 0.149 \\
\hline Child_less30 & $-0.57^{* * *}$ & 0.197 & $-0.49^{* *}$ & 0.215 \\
\hline \multicolumn{5}{|l|}{ Education } \\
\hline Secondary & $0.828^{* *}$ & 0.383 & 0.655 & 0.421 \\
\hline Tertiary & $1.336^{* *}$ & 0.44 & $1.07^{* *}$ & 0.496 \\
\hline \multirow{3}{*}{$\begin{array}{l}\text { Husb_education } \\
\text { Secondary } \\
\text { Tertiary }\end{array}$} & & & & \\
\hline & 1.01 & 1.18 & 0.949 & 1.19 \\
\hline & 1.55 & 1.18 & 1.47 & 1.19 \\
\hline Active_and_working & $1.55^{\star * *}$ & 0.22 & $1.6^{* * *}$ & 0.25 \\
\hline \multirow{3}{*}{$\begin{array}{l}\text { Husb_status } \\
\text { Husb_status2 } \\
\text { Husb_status3 }\end{array}$} & & & & \\
\hline & $0.54^{* *}$ & 0.247 & $0.648^{\star *}$ & 0.275 \\
\hline & 0.313 & 0.366 & 0.436 & 0.4 \\
\hline Religion & & & $-0.422^{* *}$ & 0.19 \\
\hline Husb_religion & & & -0.11 & 0.19 \\
\hline Couple_top & & & $-0.48^{*}$ & 0.247 \\
\hline \multirow{4}{*}{$\begin{array}{l}\text { Couple_most } \\
\text { Profession_most } \\
\text { Profession_top }\end{array}$} & & & 0.125 & 0.282 \\
\hline & & & 0.13 & 0.305 \\
\hline & & & 0.163 & 0.258 \\
\hline & \multicolumn{2}{|c|}{$\begin{array}{l}\text { Observations: } 1219 \\
\text { Wald Chi2 }(10)=131.21 \\
\text { Prob }>\text { Chi2=0.0000 } \\
\text { Pseudo R2 }=0.2033\end{array}$} & \multicolumn{2}{|c|}{$\begin{array}{l}\text { Observations: } 1039 \\
\text { Wald Chi2 }(10)=128.78 \\
\text { Prob }>\text { Chi2 }=0.0000 \\
\text { Pseudo R2 }=0.227\end{array}$} \\
\hline & \multicolumn{2}{|c|}{ Significance: ${ }^{*} .1^{* \star} .05^{* * *} .01$} & & \\
\hline
\end{tabular}

The most relevant explanatory factor for explaining "sharing with the husband" is active and_working, which has a highly significant positive effect: that is, employed women have greater possibilities of splitting domestic tasks with their partner. This variable stays robust across models. Employment status of the husband also has an effect on "sharing": in particular, having a husband in the second category of employment status increases the odds of sharing. This result, which remains constant across the two models, points against the validity of the NHE-related hypothesis; as I argued beforehand, according 
to the latter, employment status of the husband should have a negative effect on equal distribution of housework. Thus, the "social capital" mechanism could again be working here. A mechanism in this regard could be the following: the higher the employment status of the husband, the greater the interest of the woman in investing in human capital (due to spillover effects), and the lower her interest in investing time/effort in housework, which she ends up sharing with the husband.

In Table 3, we can observe that age has a negative effect on sharing; this is probably capturing a generational effect as younger women are more likely not to accept a traditional division of labor. Having children older than 14 living at home brings more inequality into the couple's distribution of tasks, but having younger children does not seem to have the same effect (child_less3 and child_less14 are not significant in model 2). Religiosity of the woman has a negative effect: the more "traditional" the woman, the less likely she is to share housework. As for the different types of women, in this case, only the variable couple_top has a substantive effect, and it goes in a coherent direction: "couple-centered" woman are less likely to share responsibilities with the husband.

In order to have a better notion of the results in Table 3, I have run different simulations that should allow us to observe the substantive effect that each of the main independent variables has on the probability of the dependent variable. I consider an "ideal" type of woman, which I call woman (a), and I suppose that she is a non-active woman, with three children living at home (one under 3, one under 14 and one over 14 years old), religious and whose husband is located in the lowest category of employment status. The other variables (age, education, etc.) have the mean value of the sample. With the estimated model in Table 3, I calculate the probability that this woman shares half of the domestic responsibilities with her husband: 0,0205 (that is, $2 \%$ ). Next, I change some of the characteristics of this woman and I calculate the probability that she shares domestic tasks with the husband, as well as the difference of this probability with respect to the probability obtained for woman (a). Specifically, I check the differences of the woman being active instead of inactive, having a medium-status employed husband instead of a low-status one, and being not-religious instead of religious. In the next diagram we can see the results:

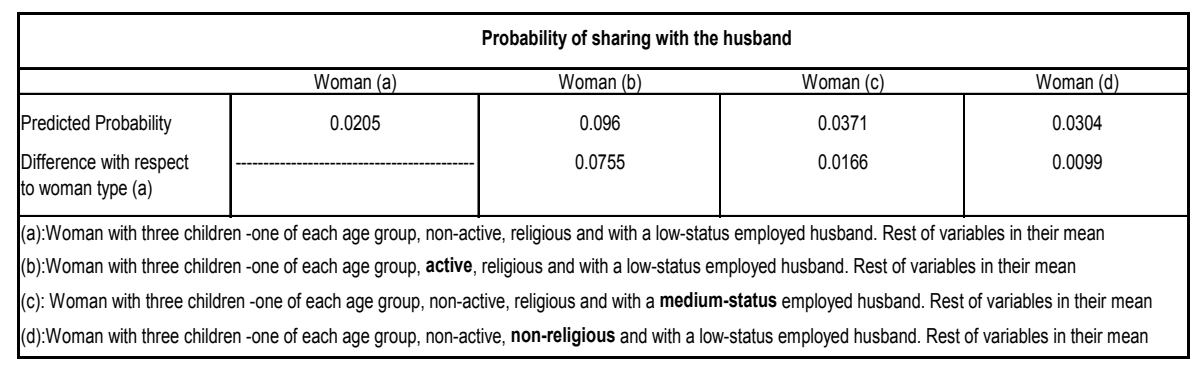


There are not many differences between the outcomes of each of the types: in fact, the probability remains pretty low in all cases. The greatest difference is made by the change in the employment status of the woman; in other words, being active (and employed) is what most increases the probability of sharing responsibilities with the husband. An increase in the employment status of the husband also increases this probability, as well as not being religious, but they do it to a much lesser extent.

In Table 4 we can observe the results of the multinomial model for housework4; in this table, the results for each of the categories have to be interpreted in relation with the base category, which is category 1 of housework (that is, being a woman who is totally responsible for domestic tasks). This table provides new information on the correlates of being a woman who shares domestic responsibilities with people other than their couple (category 3 ), and being a woman who hardly has any or has no domestic responsibilities (category 4). In the case of category 2, the results are the same as for the regressions with housework2 above (the dependent variable is the same: sharing with the husband).

Table 4.

Explanatory model for division of domestic labor (Housework4)

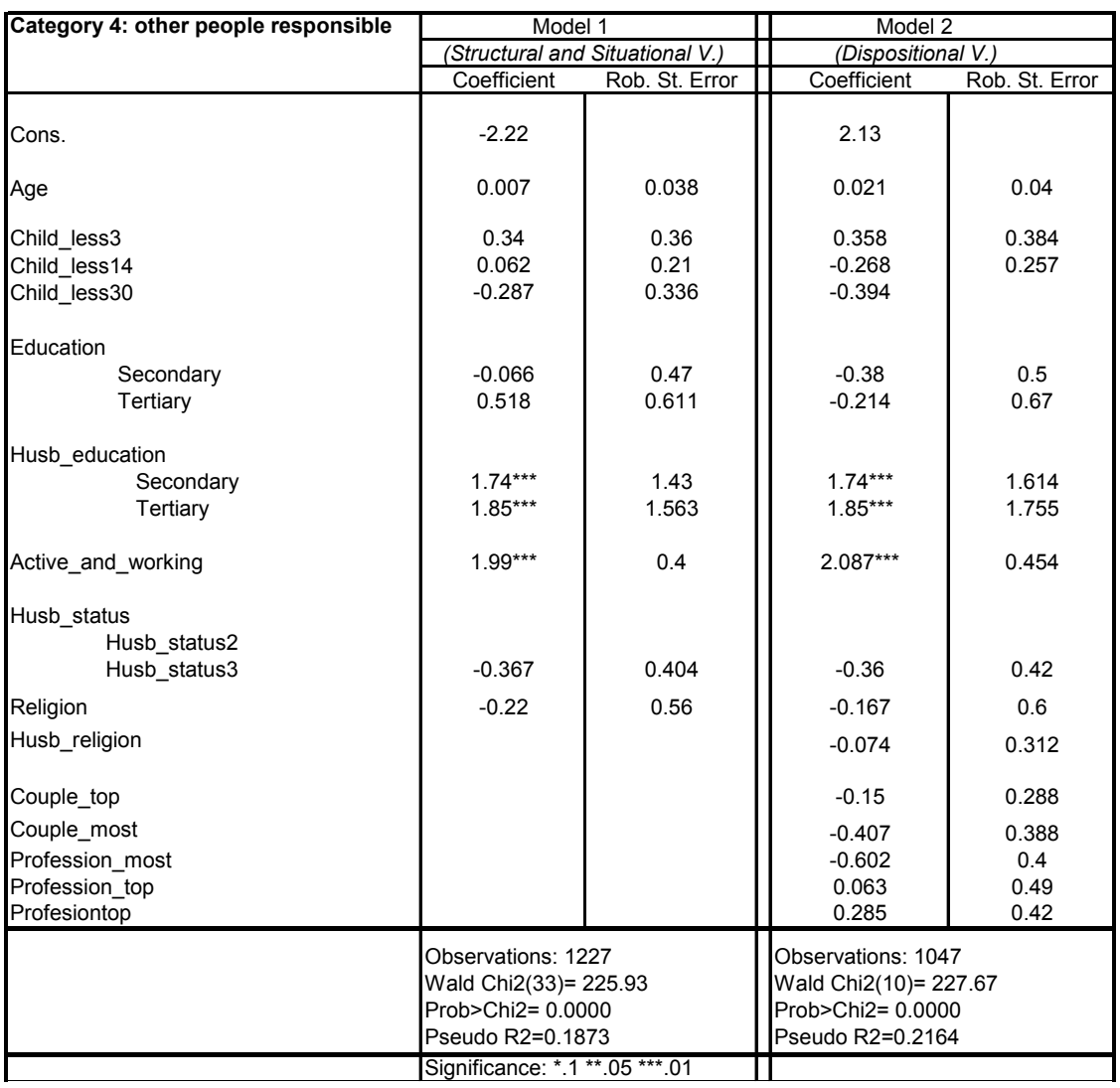




\begin{tabular}{|c|c|c|c|c|}
\hline \multirow[t]{3}{*}{ Category 2: Share with couple } & \multicolumn{2}{|c|}{ Model 1} & \multicolumn{2}{|c|}{ Model 2} \\
\hline & \multicolumn{2}{|c|}{ (Structural and Situational V.) } & \multicolumn{2}{|c|}{ (Dispositional V.) } \\
\hline & Coefficient & Rob. St. Error & Coefficient & Rob. St. Error \\
\hline Cons. & $-3.39^{* *}$ & 1.31 & $-2.97^{\star *}$ & 1,42 \\
\hline Age & -0.026 & -0.025 & -0.017 & 0.0278 \\
\hline Child less3 & -0.197 & 0.24 & -0.115 & 0.264 \\
\hline Child_less14 & $-0.316^{\star *}$ & 0.152 & -0.192 & 0.167 \\
\hline Child_less 30 & $-0.555^{\star *}$ & 0.244 & $-0.534^{*}$ & 0.265 \\
\hline \multicolumn{5}{|l|}{ Education } \\
\hline Secondary & $0.792^{* *}$ & 0.383 & 0.626 & 0.416 \\
\hline Tertiary & $1.313^{* * *}$ & 0.46 & $1.08^{* *}$ & 0.49 \\
\hline \multicolumn{5}{|l|}{ Husb_education } \\
\hline Secondary & 0.66 & 1.07 & 0.558 & 1.08 \\
\hline Tertiary & 1.17 & 1.11 & 1 & 1.12 \\
\hline Active_and_working & $1.59^{* * *}$ & 0.23 & $1.608^{* * *}$ & 0.265 \\
\hline \multicolumn{5}{|l|}{ Husb_status } \\
\hline Husb_status2 & $0.53^{\star *}$ & 0.248 & $0.58^{\star *}$ & 0.27 \\
\hline Husb_status3 & 0.32 & 0.39 & 0.419 & 0.42 \\
\hline Religion & & & $-0.37^{*}$ & 0.196 \\
\hline Husb_religion & & & -0.194 & 0.189 \\
\hline Couple_top & & & -0.299 & 0.254 \\
\hline Couple_most & & & -0.148 & 0.293 \\
\hline Profession_most & & & 0.01 & 0.322 \\
\hline Profession_top & & & 0.168 & 0.736 \\
\hline \multirow[t]{3}{*}{ Category 3: share with other people } & \multicolumn{2}{|c|}{ Model 1} & \multicolumn{2}{|c|}{ Model 2} \\
\hline & \multicolumn{2}{|c|}{ (Structural and Situational V.) } & \multicolumn{2}{|c|}{ (Dispositional V.) } \\
\hline & Coefficient & Rob. St. Error & Coefficient & Rob. St. Error \\
\hline Cons. & -4.77 & 2.87 & -3.6 & 2.34 \\
\hline Age & 0.046 & 0.079 & 1.36 & 0.958 \\
\hline Child_less3 & 1.61 & 0.7 & 1.37 & 0.958 \\
\hline Child_less14 & 0.837 & 0.45 & 0.687 & 0.522 \\
\hline Child_less 30 & 0.549 & 0.567 & 0.198 & 0.699 \\
\hline \multicolumn{5}{|l|}{ Education } \\
\hline Secondary & 1.27 & 1.11 & 1.193 & 1.225 \\
\hline Tertiary & 1.2 & 1.368 & 0.789 & 1.63 \\
\hline \multicolumn{5}{|l|}{ Husb_education } \\
\hline Secondary & 1.73 & 7.58 & 1.57 & 6.12 \\
\hline Tertiary & 1.81 & 7.58 & 1.66 & 6.12 \\
\hline Active_and_working & 2.29 & 7.58 & 2.131 & 6.12 \\
\hline \multicolumn{5}{|l|}{ Husb_status } \\
\hline Husb_status2 & $-1.57^{*}$ & 0.91 & $-0.225^{*}$ & 1.192 \\
\hline Husb_status3 & -0.069 & 0.91 & -0.77 & 1.13 \\
\hline Religion & & & $-1.832^{* * *}$ & 0.668 \\
\hline Husb_religion & & & 0.925 & 0.658 \\
\hline Couple_top & & & -0.775 & 0.77 \\
\hline Couple_most & & & 1.57 & 1.19 \\
\hline Profession_most & & & 0.827 & 1.237 \\
\hline Profession_top & & & -0.305 & 0.845 \\
\hline
\end{tabular}

RIS, VOL. 67, No 1, ENERO-ABRIL, 83-105, 2009. ISSN: 0034-9712 
We can observe that the regression models do not provide much information on the determinants of category 3. Husband's employment status is significant and negative; thus, it goes in the contrary direction to that for category 2 (so, it seems that "sharing with other people" might be a substitute to "sharing with the husband"). Religion is the only attitudinal variable that is significant, and it maintains the same sign negative as before. Thus, women with more traditional values are less likely to share, either with the husband or with other people. In general, the most insightful results in Table 4 are those for the fourth category. They show that those women who are more likely not to be responsible for domestic tasks are those who are active and employed, and those whose husbands have the highest level of education. Indeed, while the employment status of the husband does not have an effect on this category, both secondary and tertiary education of the husband have a very important positive effect. These variables might be capturing the "wage" of the husband (the higher the wage, the greater the possibility to buy market substitutes for domestic work).

In general, the results of the empirical test show that the NHE hypothesis- from which we expected occupational status of husbands to have a negative effect on wives's LM participation and attainment- can be rejected in the Spanish case. Spanish women benefit from having a medium-status employed husband, and they are more likely to participate in the LM and to be employed if their husbands have medium labor status than if they have low employment status (everything else being equal). In fact, the results in this paper are mostly supportive of the social capital hypothesis -from which we expect women to benefit from the LM resources of their husbands with regards to their own LM participation. Moreover, the results are also contrary to the NHE hypothesis with relation to the distribution of household labor within families: employment status of the husband is having a positive effect on the equal distribution of housework between members of the couple. It therefore seems that the social capital hypothesis may be working in this case: women with more qualified husbands might have a higher level of human capital, and therefore might be more interested in investing more of their time in paid work (rather than in housework), and -in consequence- their husbands might end up doing a part of the housework that is not being done by them.

We have observed that the most powerful variable explaining the degree of engagement in housework responsibilities of the woman is the LM position of the woman herself (this is, being active and employed). This makes sense, and may even appear somewhat tautological: non-employed and/or non-active woman are likely to be dedicating most of their time to housework and are less likely to share this with other people (either the husband or other people). Yet, in cases of women not totally responsible for domestic tasks, the distribution of these tasks within the family is explained by additional variables (other than the LM position of the woman): having a husband with a higher level of education (and therefore a relatively higher wage) increases the likelihood of the woman not being responsible for the housework; this is probably because the couple can afford to pay for external assistance (e.g. a hired person to do the housework). Furthermore, attitudinal variables such as not being a religious (traditional) woman explain lower levels of engagement in housework, as well as shared housework. 


\section{Conclusions}

In this paper, I have performed an in-depth analysis on patterns of division of household labor within Spanish families. I have presented a somewhat new perspective on the issue, inspired by the well-established literature on careers of couples in industrialized societies. This has led me to establish a theoretical link between the degree of engagement of women in housework responsibilities and husband's employment status.

Similar to authors like Bernardi (1999), I have presented two opposed hypotheses, which have then been tested using a sample of survey data on Spanish women: that of the NHE framework-which is based on Becker's model of the economy of the familyand the social capital (or sociological) one- which is based on Coleman's concept of Social Capital. The results have allowed us to reject the NHE hypothesis, from which we would have expected a positive effect of husband's employment status on the degree of housework responsibilities acquired by the woman. The results point towards the existence of a low effect of the husband's employment status on this woman's decision (that is, the husband's work status is largely insignificant), and of a negative effect, when there is one. Indeed, women with medium employment status's husbands are more likely to not be doing the totality of the housework by themselves (and they are more likely to be sharing them with their couple), than women with lower employment status's husbands. Additionally, and at the same time, the higher the education of the husband, the more likely the woman is to not be responsible for the housework -and that somebody else external to the couple is responsible for it.

I would argue that this study has enabled us to shed some more light on what could be described as the "black box" of household labor. I have started the article by rejecting the assumption that all families behave equally to the challenges of female incorporation into the LM, and I have proceeded to analyze the determinants of variation in housework distribution patterns: I have observed that different structural, situational and attitudinal characteristics of family members are relevant in this regard. That is, not all women are equal and not all families are equal, and that these standing and relational differences influence the way household labor is distributed between family members.

\section{BIBLIOGRAPHY}

BECKER, G. S. (1981), Treatise on the family, Cambridge, Harvard University Press.

BERNARDI, F. (1999a), "Does the Husband Matter? Married Women and Employment in Italy", European Sociological Review, vol. 15, n³, pp. 285-300.

BERNARDI, F. (1999b), Donne Fra Famiglia E Carriera. Strategie Di Coppia E Vincoli Sociali, Milano, Laboratorio Sociologico Franco Angeli. 
BERNASCO, W., P.M. GRAAF y W.C. ULTEE (1998), "Coupled Careers. Effects of Spouse's Resources on Occupational Attainment in the Netherlands", European Sociological Review, vol. 14, n¹, pp.15-31.

BLOSSFELD, H. y S. DROBNIC (2001), Careers of Couples in Contemporary Societies, Oxford, Oxford University Press.

BRYNIN, M. y J. SCHUPP (2000), "Education, Employment and Gender Inequality Amongst Couples. A comparative analysis of Britain and Germany", European Sociological Review, vol.16, n 4, pp. 349-365.

COLEMAN, J. (1988), "Social capital in the creation of human capital", American Journal of Sociology, vol. 94, pp. 95-120.

DELGADO, M. (1995). "Spain." en H. BLOSSFELD (coord.), The New Role of Women. Family Formation in Modern Societies, Boulder, Westview Press.

ESPING-ANDERSEN, G. (1990), The three worlds of welfare capitalism, Cambridge, Polity.

ESPING-ANDERSEN, G., A. HEMERIJCK, y J. MYLES, with D. GALLIE (2002), Why We Need a New Welfare State, Oxford, Oxford University Press.

FLAQUER, L. (2002), "Political intervention in family policy in Europe and the USA", en A.Carling, S. Duncan y R.Edwards (coord.), Analysing Families: Morality and Rationality in Policy and Practice, London, Routledge, pp. 84-92.

GANZEBOOM, H.B.G. y D. J.TREIMAN (2003), "Three Internationally Standardised Measures for Comparative Research on Occupational Status". Available from http://home.scw.vu.nl/ ganzeboom/pdf/gt2003.pdf

GANZEBOOM, H.B.G. y D. J.TREIMAN (1993) «International Stratification and Mobility File: Conversion Tools». Available from www.fss.uu.nl/soc/hg/ismf

GERSHUNY, J., GODWIN, M. y S. JONES (1994), «The Domestic Labor Revolution: A Process of Lagged Adaptation?», en M. Anderson, Bechhofer, F. y Gershuny (coord.), The Social and Political Economy of the Household, Oxford, Oxford University Press.

GONZÁLEZ-LÓPEZ, M. J. (2001) "Spouses' Employment Careers in Spain”, en H. Blossfeld y S. Drobnic (coord.) Careers of Couples in Contemporary Societies. From Male Breadwinner to Dual Earner Families, Oxford, Oxford University Press.

(2000) "Partnership Formation in the Context of Women's Growing Educational Attainment.", Available from www.ced.uab.es/publicacions/papersPDF/text180.pdf

GONZÁLEZ-LÓPEZ, M. J. et al. (2000). Gender Inequalities in Southern Europe: Women, Work, and the Welfare in the 1990s, London, Frank Cass Publishers.

GRONAU, R. (1976), "Leisure, Home Production and Work -The Theory of Allocation of Time Revisited", Hebrew University Jerusalem - Department of Economics, NBER Working Paper nº WO137.

HAKIM, C. (1993), "Notes and Issues. The myth of rising female employment", Work, Employment, and Society, vol. 7, n¹, pp. 97-120. 
HAKIM, C. (1996), Key Issues in Women's Work. Female heterogeneity and the polarisation of women's employment, New Jersey, Athlone.

HERSCH, J. (1991), "Male-Female differences in hourly wages", Industrial and Labor Relations Review, vol. $44, n^{\circ} 4$, pp. 746-759.

HERSCH, J. y L.S. STRATTON (1994), "Housework, Wages, and the Division of Housework Time for Employed Spouses", The American Economic Review, vol. 84, n² 2, pp. 120-5.

KAUFMAN, G. y P. UHLENBERG (2000), ,The influence of Parenthood on the Work Effort of Married Men and Women“, Social Forces, vol. 78, n 3, pp. 931-947.

LEHRER, E. L. (1995) "The effects of religion on the labor supply of married women", Social Science Research, vol. 24, n³, pp. 281-301.

MOHD NOOR, N. (2001) Work, family and women's well-being: selected papers, Kuala Lumpur, International Islamic University Malaysia Press.

MORALES, L. (2000), "Political Participation: Exploring the Gender Gap in Spain, South European Society \& Politics, vol. 4, no 1, pp. 223-247.

PAHL, J. (1983), "The Allocation of Money and the Structuring of Inequality within Marriage", Sociological Review, vol. 31, pp. 237-62.

PARKMAN, A. M. (1998), "Why are married women working so hard?", International Review of Law and Economics, vol. 18, n¹, pp. 41-50.

SCHERER, S. (2004) "Stepping-Stones or Traps? The Consequences of Labor Market Entry Positions on Future Careers in West Germany, Great Britain and Italy", Work, Employment and Society, vol. 12, n8, pp. 369-94.

SHELTON, B.A. y D. JOHN (1996) "The division of household labor", Annual Review of Sociology, vol. 22, pp. 299-322.

ULTEE, W. C. y W. J. DESSENS (1988) "Why Does Unemployment Come in Couples? An Analysis of (Un)Employment and (Non)Employment Homogamy Tables for Canada, the Netherlands and the United States in the 1980s.", European Sociological Review, vol. 4, n²2, pp. 111-22. 


\section{APPENDIX}

Categories of Household Labor. Sample Distribution

\begin{tabular}{|c|c|c|c|c|c|}
\hline 1. Totally responsible & 2. Share wth couple & 3. Share with others & 4. Other people responsible & 5. Other cases & Total \\
\hline 1246 & 138 & 14 & 48 & 1062 & 2508 \\
$49.70 \%$ & $5.50 \%$ & $0.50 \%$ & $2 \%$ & $42.30 \%$ & $100 \%$ \\
\hline
\end{tabular}

\section{Descriptive Statistics of the Variables}

\begin{tabular}{|l|c|c|c|c|c|}
\hline Variable & Observations & Mean & Standard Deviation & Min & Max \\
\hline Active & 4013 & 0.51 & 0.499 & 0 & 1 \\
Activeandworking & 4013 & 0.39 & 0.48 & 0 & 1 \\
Housework2 & 1384 & 0.09 & 0.299 & 0 & 1 \\
Housework4 & 1446 & 1.21 & 0.622 & 1 & 4 \\
& & & & & \\
Age & 4021 & 32.01 & 8.67 & 18 & 49 \\
Childless3 & 4021 & 0.19 & 0.43 & 0 & 2 \\
Childless14 & 4021 & 0.62 & 0.84 & 0 & 6 \\
Childless30 & 4021 & 0.39 & 0.82 & 0 & 7 \\
Education & 4021 & 1.92 & 0.61 & 1 & 3 \\
Husbeducation & 2103 & 2 & 0 & 2 & 2 \\
Manisei & 2255 & 1.63 & 0.67 & 1 & 3 \\
& & & & & \\
Religion & 3998 & 1.45 & 0.76 & 0 & 2 \\
Husbreligion & 2624 & 1.24 & 0.81 & 0 & 2 \\
Couplebeforeotherthings & 3756 & 0.59 & 0.49 & 0 & 1 \\
Couplemostimportant & 3900 & 0.733 & 0.44 & 0 & 1 \\
Professionveryimportant & 3851 & 0.77 & 0.41 & 0 & 1 \\
Professionbeforeotherthings & 3734 & 0.65 & 0.47 & 0 & 1 \\
\hline
\end{tabular}

